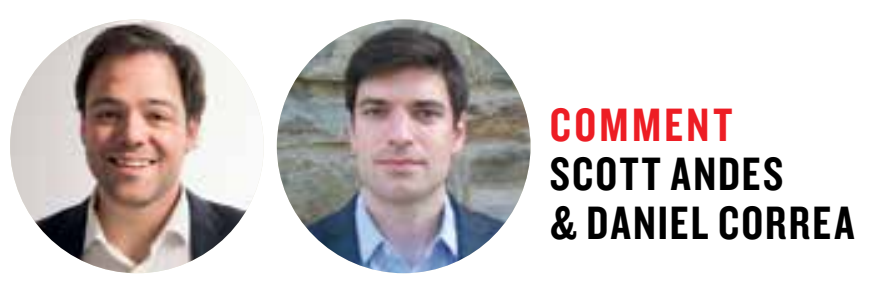

\title{
BOOSTING RESEARCH FUNDING AS UNCERTAINTY REIGNS
}

With government funding plummeting, researchers in the United States need to find alternative sources.

$\mathrm{T}$ 1 he United States' reign as the undisputed global leader in science and technology is under intense pressure. As its international peers surge ahead, the country's academic research output is diminishing, with looming budget cuts threatening to further curtail productivity.

One proxy for this changing status is highquality publication rates. In 2016, US researchers contributed to more than 25,800 articles in journals included in the Nature Index, more than double that of their closest competitors in China, who produced 9,700 articles. But the US figure represents a fall of some 1,500 articles from 2012, while China's total output increased by 3,000 articles. US authorship as a share of the world total, measured by weighted fractional count, also fell from $37.2 \%$ in 2012 to $33.6 \%$ in 2016. During that same period, China's share rose from $9 \%$ to $13.5 \%$.

The US's loosening grip on research in part reflects a long-term decline in its commitment to science. In the $1960 \mathrm{~s}$, federal investment in $\mathrm{R} \& \mathrm{D}$ reached as high as $2.23 \%$ of GDP. In 2016 that had plummeted to $0.77 \%$. In 1995 , the US ranked fourth globally for R\&D expenditures as a share of GDP. By 2015, it ranked tenth.

Diverting funding from science impedes economic growth. Economists have found that companies underinvest in research because of the risk of competing firms appropriating any resulting benefits. The federal government's $\mathrm{R} \& \mathrm{D}$ budget is designed in part to overcome this market failure. Declining spending therefore translates into slower economic growth.

The fiscal outlook for US science is unlikely to improve in the near term. President Donald Trump's proposed budget would decrease federal R\&D by $17 \%$ - a greater annual cut than any in the post-war era. Even if the president's budget isn't ratified by Congress, the multidecade post-partisan support for science is no longer a given. Instead, the country must make available resources work harder, and find alternative sources of funding.

Federal research agencies have restrictions on using funds from non-governmental sources. To provide greater flexibility, Congress created separate foundations for some agencies, including the National Institutes of Health and the Food and Drug Administration, which can accept charitable contributions to achieve their scientific missions. There are opportunities for closer collaboration between federal and philanthropic funders in the grant application review process.

While companies contributed more than a quarter of the investment in US basic research in 2015, these funds accounted for only $7 \%$ of private sector spending on overall R\&D. Companies are reluctant to invest in basic research because of the significant risk of failure in earlystage science. Andrew Lo, a professor of finance at MIT, advocates the establishment of biomedical research 'megafunds'. By pooling thousands

\section{FUNDING SLUMP}

Federal investment in research and development in the United States has been declining since the 1960s. These funds account for more than half of the total spending on basic research in the country.

\section{FEDERAL INVESTMENT IN R\&D AS A PERCENTAGE OF GDP,} 1960-2016

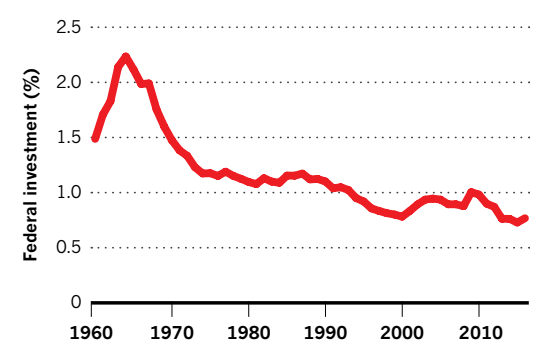

INVESTMENT IN BASIC RESEARCH BY FUNDER, 1960-2015

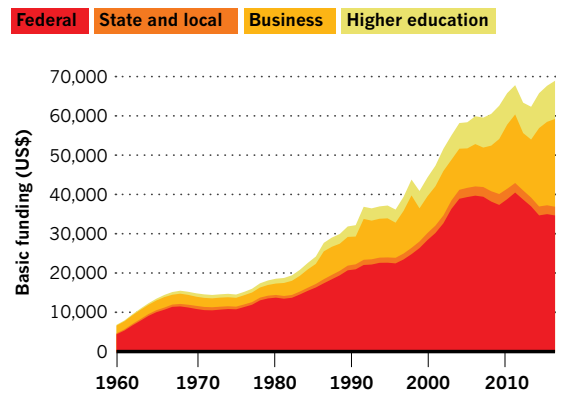

of cancer trials into one portfolio, for example, such a fund could create predictable aggregate outcomes that become reliable investments.

US universities also need to do more to attract private sector money. In 2015, just over $5 \%$ of total university R\&D came from industry. Instead of licensing individual technologies to specific companies, universities should form partnerships with firms that span multiple projects and research areas. For example, drug maker Novartis has invested US\$20 million with the University of Pennsylvania to create the Novartis-Penn Center for Advanced Cellular Therapies, which supports hundreds of partnerships between the two organizations. At the same time, tenure requirements should reward academics that have strong track records of engaging with industry.

State and local governments can do their part to improve the efficiency of research commercialization by funding university efforts that experiment with new models. Promis ing approaches include the National Science Foundation's Innovation Corps, which connects researchers with potential customers as a way to better predict the market viability of a scientific advance.

While state governments will never fund the lion's share of US R\&D (currently they support $1.6 \%$ ), governors can often use targeted funds and public advocacy to leverage private and civic capital. For example, the Indiana Bioscience Research Institute (IBRI) - a universityindustry partnership established in 2012 to promote research in the life sciences - was initially supported by a US $\$ 25$ million investmen by the state of Indiana. IBRI has raised an additional US $\$ 125$ million from non-governmental sources, most of it from the philanthropic foundation Lily Endowment in Indianapolis.

With pending budget debates in Washington DC, improving the rate of return from existing funding is now more necessary than ever.

Scott Andes is a fellow at the Brookings Institution. Daniel Correa is former assistant director for innovation policy at the White House Office of Science and Technology Policy under President Barack Obama. 